\title{
MODEL DASAR PEMBELAJARAN INSTRUMEN REBAB BAGI ANAK-ANAK TINGKAT SEKOLAH DASAR: SEBUAH UPAYA MENGGALI NILAI-NILAI PENDIDIKAN KARAKTER MELALUI KARAWITAN JAWA
}

\author{
Kriswanto *)
}

\begin{abstract}
ABSTRAK
Dewasa ini Seni Karawitan telah mengalami perkembangan luar biasa, akan tetapi masih terdapat permasalahan, terutama yang menyangkut pendidikan karawitan bagi anak usia sekolah dasar. Gamelan Jawa sebagai media penting dalam karawitan terkonsep untuk orang dewasa dan dimainkan oleh kaum laki-laki dalam sikap duduk bersila, bukan untuk anak. Apabila mengacu pada pola pengembangan pendidikan, segala bidang keilmuan termasuk Seni Karawitan harus dimulai dari tingkat sekolah dasar. Budi Raharja (PHB 2001-2002) dalam penelitiannya telah menghasilkan Gamelan Anak dengan desain sesuai dengan kebutuhan anak, akan tetapi belum ditindaklanjuti aplikasi permainan masing-masing instrumen dan perannya dalam karawitan.

Rebab merupakan instrumen karawitan dalam kategori sulit dipelajari, terlebih untuk anak-anak tingkat sekolah dasar, dibutuhkan waktu cukup lama untuk mempelajarinya. Guna memenuhi kebutuhan tersebut diperlukan instrumen rebab yang sesuai dengan kondisi fisik anak, berikut model-model pembelajaran yang disesuaikan dengan tingkat kemampuannya. Penelitian ini khususnya pada tahun pertama bertujuan merancang model-model pembelajaran instrumen rebab meliputi pengenalan dan cara memainkannya yang disesuaikan dengan teknis musikal anak. Pada tahun kedua, merealisasikan hasil penelitian yang dicapai tahun pertama untuk disosialisasikan pada sekolah-sekolah dasar unggulan yang memiliki basic seni karawitan dan jika dimungkinkan pada sanggar seni karawitan anak di wilayah Daerah Istimewa Yogyakarta. Adapun penelitian ini dilaksanakan dengan menggunakan metode perancangan dan sosialisai.
\end{abstract}

Kata kunci: Model pembelajaran, rebab, anak-anak.

\section{PENDAHULUAN}

Melalui hasil pra-penelitian, diperoleh informasi dari para guru dan pelatih karawitan yang berpendapat bahwa anak-anak kurang mengenal tradisi Karawitan Jawa. Mereka tidak lagi mengenal lagu-lagu dolanan anak dan berbagai ricikan gamelan Jawa sebagai media ungkapnya, namun lebih mudah mengenal musik dalam tangga nada diatonik. Kondisi seperti ini merupakan salah satu akibat adanya sistem dan metode pembelajaran karawitan anak, terutama yang menyangkut ricikan dalam kategori sulit dipelajari yang hingga dewasa ini belum digarap dan dikembangkan secara

*) Kriswanto (kriswanto@gmail.com), Staf Pengajar Program studi Karawitan, Fakultas Seni Pertunjukan, Institut Seni Indonesia Yogyakarta. 
maksimal. Pembelajaran karawitan selama ini pada umumnya menggunakan metode dan materi sebagaimana dilakukan untuk orang dewasa. Akan berbeda apabila model pembelajaran, terutama ricikan rebab dilakukan dengan materi dan alat yang disesuaikan dengan kondisi anak.

Apabila anak-anak, khususnya di Jawa sudah tidak lagi mengenal gamelan dan Karawitan Jawa, kelak akan menjadi salah satu sebab bagi anak sebagai generasi penerus bangsa yang kurang berakar pada tradisi, seni, dan budayanya sendiri. Sekalipun Indonesia dewasa ini sudah dalam tataran menuju modernisasi, tidak berarti meninggalkan budaya leluhur, namun justru harus dipelihara, dilestarikan, dan dikembangkan sebagai aset budaya nasional. Anak-anak Jawa akan lebih baik apabila diberikan kesempatan yang cukup untuk mempelajari budayanya sendiri melalui karawitan yang di dalamnya mengandung pendidikan karakter meliputi bahasa, perilaku, sopan santun, dan budi pekerti.

Kondisi lingkungan dan sosial budaya telah mampu mengubah pola bermain di tempat tinggalnya. Fenomena yang berkembang dahulu, anak-anak terbiasa bermain di luar rumah terutama saat bulan purnama tiba yaitu berbagai permainan anak dan melantunkan tembang dolanan anak seperti, Jamuran, Kupu Kuwi, Padhang Bulan, dan sebagainya. Perkembangan teknologi informasi yang mendominasi semua lini mampu mempengaruhi aktivitas anak dalam bidang tradisi, sehingga mereka nyaris tidak mengenalnya, apa lagi bermain gamelan sekalipun hanya sebatas pada tingkat pengenalan dan pemahaman masing- masing ricikan. Nilai-nilai luhur yang terkandung di dalamnya seperti kebersamaan, kreativitas, saling hormat menghormati, cinta terhadap lingkungan, tampak mulai pudar. Sementara itu pendidikan dalam pengertian umum baik di rumah maupun sekolah ternyata tidak selalu diperhatikan.

\section{Tujuan Khusus}

Penelitian ini secara khusus bertujuan untuk membantu para guru dan pelatih karawitan dalam rangka melaksanakan proses pembelajaran karawitan bagi anak. Kelak para guru dan pelatih karawitan diharapkan akan dapat menggunakan Buku Model Pembelajaran Ricikan Rebab Bagi Anak ini sebagai materi pembelajaran yang disesuaikan dengan tingkat kemampuan anak. Buku-buku yang memuat tentang gending-gending bagi anak (yang kemudian disebut gending dolanan anak), telah banyak beredar dan digunakan sebagai panduan oleh para guru dan pelatuh karawitan, akan tetapi secara material dan teknis belum ada yang diperuntukkan bagi anak, terlebih yang menyangkut ricikan rebab.

Kecuali hal tersebut, penelitian ini juga dimaksudkan memberi informasi kepada para guru karawitan di berbagai sekolah dasar tentang hal-hal yang menyangkut pengetahuan karawitan, baik yang telah memiliki kompetensi mengajar maupun pengalaman di bidang karawitan namun tidak memiliki pendidikan karawitan. Selama ini materi yang diajarkan pada anak-anak seusia sekolah dasar masih terbatas menggunakan ricikan wingking, belum menyentuh penggunaan ricikan ngajeng. Dengan demikian penelitian ini juga bertujuan untuk menyempurnakan 
mata pelajaran Seni Karawitan yang masuk dalam kategori muatan lokal.

\section{Urgensi Penelitian}

1. Bersifat terapan; artinya dilakukan dengan membuat rancangan atau penciptaan model pembelajaran dalam bentuk buku dan rekaman audio visual.

2. Bersifat baru; artinya hasil penelitian berupa produk baru atau memperbaharui dari buku-buku sejenis yang telah beredar dan digunakan oleh guru/pelatih karawitan. Pembaruan meliputi materi ajar terhadap ricikan rebab, berikut alatnya bagi anak dan menghasilkan luaran yang secara teknis dsesuaikan dengan tingkat kemampuan dan kejiwaan anak.

3. Bersifat temuan; materi pelajaran karawitan pada sekolah dasar dengan memperhatikan kemampuan fisik, teknis memainkan ricikan rebab dengan merancang dan mengidentifikasi tingkat-tingkat kesulitan secara gradual untuk menciptakan solusinya.

4. Nilai HAKI; hasil penelitian direncanakan akan didaftarkan sebagai temuan yang bernilai Hak atas Kekayaan Intelektual dan dipublikasikan secara luas.

5. Nilai Ekonomi; Guru/Pelatih Karawitan dan murid dapat menggunakan hasil penelitian ini secara efektif dan efisien dalam konteks waktu dan biaya.

6. Pengembangan IImu; bertujuan mengembangkan ilmu pengetahuan karawitan (karawitanologi) khususnya menyempurnakan materi dan metode pembelajaran karawitan terhadap anak-anak di tingkat sekolah dasar.

7. Kerjasama antar lembaga; proses penelitian ini melibatkan para siswa sekolah dasar di Kecamatan Sedayu Kabupaten Bantul sebagai laboratorium. Adapun Jurusan Karawitan, Fakultas Seni Pertunjukan, Institut Seni Indonesia Yogyakarta sebagai basis kegiatan para peneliti.

\section{Target Penelitian}

Target capaian pada tahun I, yaitu telah dapat dirancang materi meliputi:

1. Modul Pembelajaran Ricikan Rebab,

2. Fisik ricikan rebab (ukuran $1 / 2$ ) sesuai dengan kondisi fisik anak tingkat sekolah dasar,

3. Uji materi dalam skala terbatas, dan

4. Produk akhir hasil uji materi.

\section{METODE}

Penelitian yang akan dilakukan ini merupakan jenis penelitian pengembangan atau Reasearch and Development (RND). Penelitian pengembangan adalah metode yang digunakan untuk menghasilkan produk tertentu dan menguji efektivitas produk tertentu (Sugiono, 2006). Pendapat lain terhadap penelitian pengembangan adalah suatu proses untuk menghasilkan produk melalui pengembangan dan validasi produk-produk (Soenarto, 2005). Adapun yang dimaksud produk tersebut dapat berupa prototype, model, paket, yang akan digunakan dalam pembelajaran karawitan. Penelitian ini akan menghasilkan materi pembelajaran instrumen rebab dalam karawitan bagi anak-anak anak tingkat sekolah dasar.

Analisis data dalam penelitian ini menggunakan teori Trianggulasi yaitu melihat data sesuai dengan objek yang diteliti. Semua data yang telah terkumpul kemudian direduksi dan diarahkan ke sasaran objek penelitian. 
Adapun metode penelitian yang akan dilakukan yaitu ditempuh dengan melalui tahapan observasi, eksplorasi dan pembentukan, kemudian dilanjutkan dengan uji ahli, uji empirik, dan uji lapangan. Penjelasan lebih lanjut tentang metode tersebut adalah sebagai berikut.

Observasi

Pengamatan selama pra penelitian dilakukan untuk mendapatkan data, kegiatan praktik karawitan di sekolahsekolah dasar dan perkumpulan/sanggar karawitan anak. Pengamatan para siswasiswi sekolah dasar baik yang memiliki kemampuan apresiasi karawitan maupun yang belum terhadap seni karawitan. Hasilnya berupa keluhan, harapan dan usulan-usulan khususnya dari para siswasiswi sekolah dasar agar peneliti menciptakan suatu rancangan instrumen dan gending-gending baru untuk keperluan anak yang disesuaikan dengan kemampuan fisik dan kejiwaan para siswa-siswi sekolah dasar.

Eksplorasi

Melalui hasil observasi yang
ditemukan kemudian ditindaklanjuti
dengan mengadakan eksplorasi dengan
eksperimen-eksperimen yang disesuaikan
dengan topik penelitian sehingga
menghasilkan beberapa materi
pembelajaran instrumen rebab yang
mencakup alat (fisik instrumen rebab yang
disesuaikan dengan fisik anak).
Pembentukan materi hasil dari eksplorasi
kemudian diramu menjadi satu bentuk
format pembelajaran rebab, yaitu teknik
bermain dengan cara yang benar, sikap
pemain, teknik memainkan, kemudian
diaplikasikan dalam lagu dalam bentuk
sederhana.

Hasil dari pembentukan ini berupa perancangan materi pembelajaran rebab untuk anak, sehingga perlu ditindaklanjuti dengan tahap uji materi agar rancangan tersebut kelak dapat diterima oleh para siswa-siswi tingkat sekolah dasar yang disesuaikan dengan basic dan kejiwaan anak. Ada tiga tahap uji materi yang harus dilalui, yaitu sebagai berikut.

Uji ahli

Rancangan model pembelajaran instrumen rebab untuk anak ini perlu mendapatkan rekomendasi dari para ahli yang terkait langsung atau tidak langsung dengan bidang seni karawitan. Para ahli tersebut datang dari berbagai disiplin ilmu yang ada relevansinya dengan seni karawitan, meliputi musikologi, sosiologi, karawitanologi, dan psikologi. Kegiatan ini dapat dilaksanakan melalui seminar atau sarasehan dan pada kegiatan ini diharapkan ada saran dan masukan atau kritik untuk memperbaiki atau revisi tahap pertama.

\section{a. Uji Empirik/uji terbatas}

Rancangan model pembelajaran instrumen rebab untuk anak ini setelah diuji penguji ahli kemudian dipraktikkan pada satu grup sekolah dasar. Hasil dari praktik dengan menggunakan materi baru tersebut dapat diketahui berbagai problem yang dihadapi, baik kemudahan maupun kesulitan yang dialami para siswa-siswi selama proses pembelajaran materi baru tersebut. Temuan tentang problem pada uji empirik ini dapat dijadikan bahan untuk memperbaiki atau revisi tahap ke-2, yaitu pada rancangan model pembelajaran instrumen rebab bagi anak tingkat sekolah dasar tersebut. 


\section{b. Uji Lapangan}

Setelah melalui uji ahli dan uji empirik, kemudian rancangan model pembelajaran instrumen rebab bagi anak tingkat sekolah dasar tersebut dipraktikkan lagi oleh 3-4 grup karawitan sekolah dasar. Apabila di dalam aplikasinya masih terdapat kelemahan, perlu dilakukan revisi yang ke-3, namun apabila sudah tidak ada lagi permasalahan yang timbul, maka rancangan model pembelajaran instrumen rebab bagi anak tingkat sekolah dasar tersebut dianggap telah sempurna.

\section{HASIL PENELITIAN}

Rebab merupakan salah satu instrumen jenis gesek pada gamelan Jawa, terutama yang ada di Yogyakarta dan Surakarta (selanjutnya disebut Gaya Yogyakarta dan Gaya Surakarta). Dalam gamelan Jawa baik Yogyakarta maupun Surakarta, rebab berfungsi sebagai pamurba lagu (pemimpin lagu), yaitu menuntun jalannya alur vokal, terutama vokal sindhènan. Gamelan Jawa itu sendiri dilihat dari fisiknya dicipta dan diperuntukkan bagi orang dewasa dengan dimainkan pada posisi duduk bersila. Adapun bentuk fisik rebab adalah sebagai berikut.

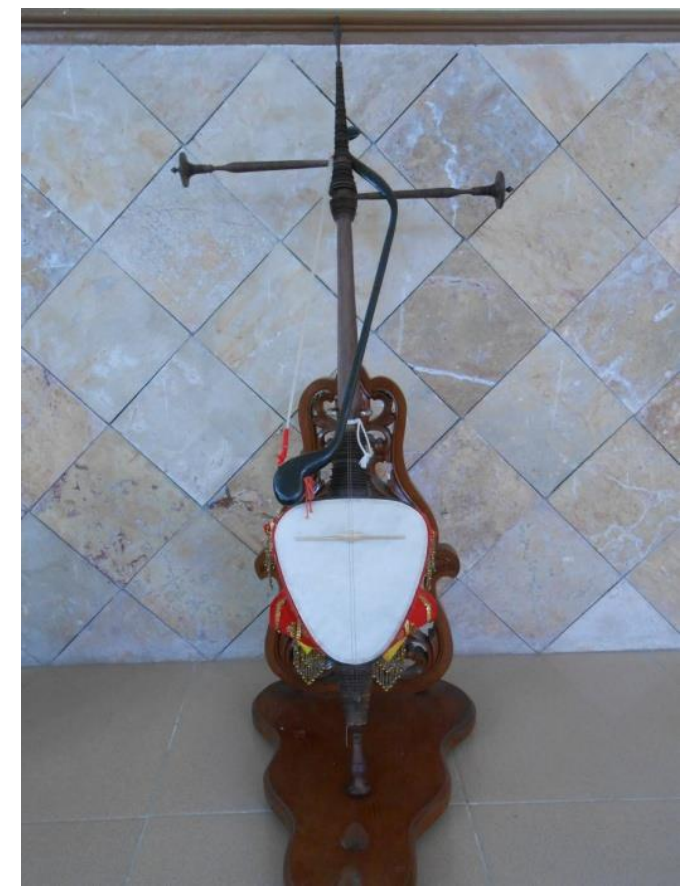

Gambar 1. Rebab ukuran standar untuk orang dewasa (Foto: Kriswanto, 2016)

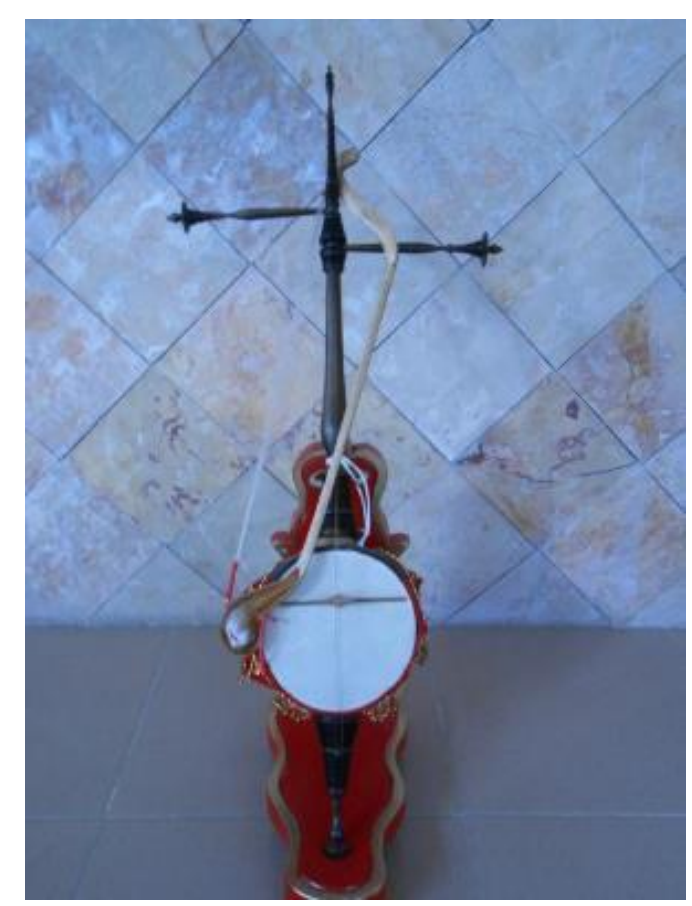

Gambar 2. Rebab ukuran mini untuk anak-anak usia sekolah dasar. (Foto: Kriswanto, 2016) 


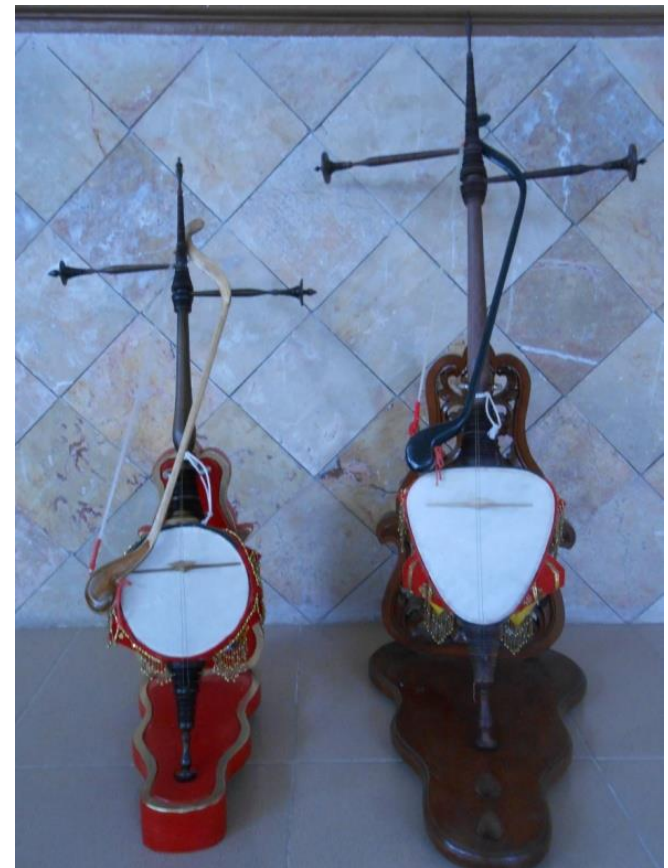

Gambar 3. Rebab ukuran mini (kiri) dan standar (kanan). (Foto: Kriswanto, 2016)

Rebab, untuk dapat dibunyikan diperlukan rangkaian lain dan pemain diharuskan mengetahui nama bagianbagian, baik pada rebab itu sendiri maupun rangkaiannya. Untuk lebih jelasnya dapat disimak sepe rti berikut.

\section{Rangkaian Rebab}

\section{a. Kosok/gesek}

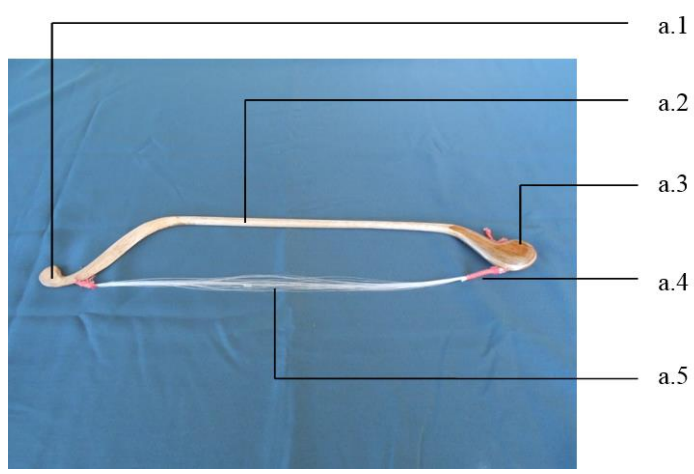

Gambar 4. Bentuk fisik kosok atau gesek (Foto: Kriswanto, 2016)

Keterangan:

a.1. Ukel/sirah bajul
a.2. Rangkung
a.3. Bendha/gayaman
a.4. Lombokan
a.5. Bobad

\section{Srenten}

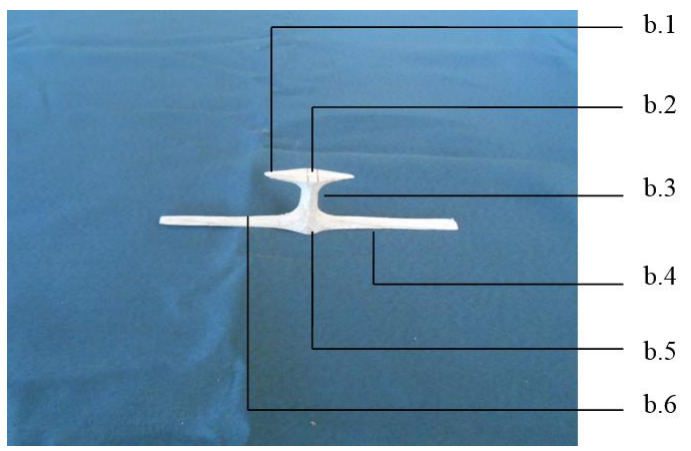

Gambar 5. Bentuk fisik srenten

(Foto: Kriswanto, 2016)

Keterangan:
b.1. Sirah
b.2. Blerekan
b.3. Jangga
b.4. Bapang
b.5. Alas
b.6. Kruwingan

\section{Nama-nama Bagian Instrumen Rebab}

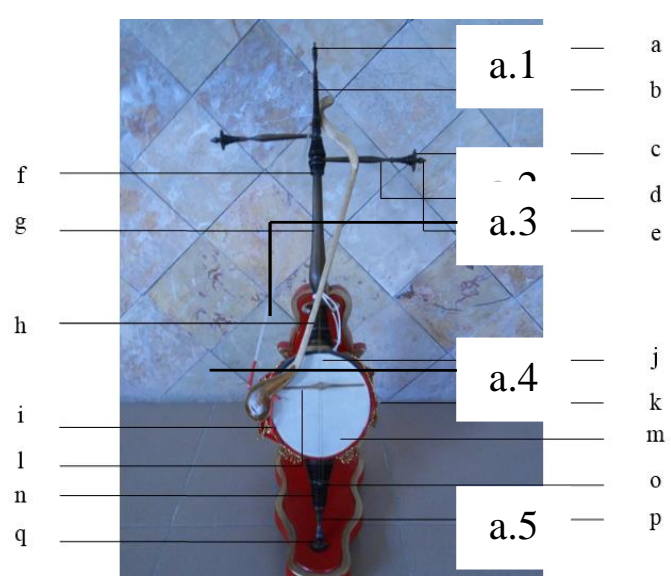

Gambar 7. Bentuk fisik rebab dan bagian-bagiannya. (Foto: Kriswanto, 2016) 
Keterangan:

a. Menur

b. Irah-irahan

c. Kupingan

d. Bahu

e. Mlathi

f. Irung-irungan

g. Watang

h. Popor atas

i. Bathokan

j. Kawat

k. Dodod

I. Srenten

m. Babad

n. Popor bawah

o. Cakil

p. Sikilan

q. Palemahan

\section{Pra Latihan}

Sebelum memainkan rebab, pemain (pengrebab) menyiapkan langkah yang sifatnya terpadu yaitu menyiapkan instrumen dengan indikator betul-betul layak dan standar sesuai dengan fungsinya.

1. Menyiapkan instrumen rebab dan rangkaiannya

Langkah ini penting untuk dilakukan agar tahu kondisi rebab yang akan dimainkan dalam keadaan standar, terutama kondisi kawat, srenten, dan kosok.

\section{Memasang srenten}

Langkah selanjutnya adalah memasang srenten pada babad untuk menyangga kawat rebab, kemudian menyetem nada 6 (nem) pada kawat pendek dan nada 2 (ro) pada kawat panjang.

\section{Menyiapkan kosok}

Kosok atau senggreng yang fungsinya untuk menggesek kawat rebab harus betul-betul bebas lemak, yaitu dengan cara menggosok bubad dengan menggunakan gondorukem.

\section{Latihan Dasar}

1. Dasar 1

Sebelum latihan bermain rebab untuk tingkat dasar, siswa diharuskan tahu elemen yang akan dimainkan, meliputi kosokan, notasi rebaban, tata jari dan posisi.

a. Kosokan

Kosokan merupakan jenis teknik untuk memunculkan bunyi akibat gesekan antara kosok dengan kawat rebab, sedang kosokan itu sendiri ada 2 jenis, yaitu kosokan maju (dengan simbol: /) dan kosokan mundur (dengan simbol: $\backslash$ ).

\section{b. Notasi Rebaban}

Notasi rebaban berbentuk angkaangka kepatihan (selanjutnya disebut notasi kepatihan). Cara membaca notasi tersebut sama dengan notasi pada karawitan, yaitu untuk laras slendro: 1 (ji), 2 (ro), 3 (lu), 5 (ma), 6 (nem), $i$ (ji alit), dan untuk laras pelog: 1 (ji), 2 (ro), 3 (lu), 4 (pat), 5 (ma), 6 (nem), 7 (pi), I (ji alit).

\section{c. Tata Jari dan Posisi}

Tata jari atau penjarian adalah pembagian peran masing-masing jari tangan kiri dalam memunculkan nada-nada pada kawat rebab. Adapun tata jari dalam wilayah gembyang (oktaf) pada rebab dibedakan menjadi beberapa macam yang kemudian disebut posisi, misalnya posisi I, posisi II, posisi III. Masing-masing posisi berperan memunculkan nada-nada yang berbeda. Tata jari tersebut dalam implementasinya diberi simbol a (jari telunjuk), b (jari tengah), c (jari 
manis), dan d (jari kelingking) seperti

contoh berikut.
Tata jari untuk teknik rebaban laras slendro pathet manyura:

Posisi I:

$\begin{array}{llllll}\text { Nada } & : & \text { y } & 1 & 2 & 3 \\ \text { Tata jari } & : & - & \text { a } & \text { b } & \text { c }\end{array}$

Posisi II:

$\begin{array}{llllll}\text { Nada } & : & 3 & 5 & 6 & \text { ! } \\ \text { Tata jari } & : & \text { a } & \text { b } & \text { c } & \text { d }\end{array}$

Posisi III:

$\begin{array}{llllll}\text { Nada } & : & 6 & 1 & @ & \# \\ \text { Tata jari } & : & \text { a } & \text { b } & c & \text { d }\end{array}$

Posisi-posisi pada laras slendro pathet sanga, nem, pelog untuk semua pathet diatur berbeda. Untuk belajar tingkat awal (pemula), berikut diberikan panduan praktis, terutama untuk siswa-siswi sekolah dasar.

$\begin{array}{cccccc}\text { Kosokan } & : & / & \text { I } & / & \text { । } \\ \text { Not. Reb } & : & \mathbf{2} & \mathbf{1} & \mathbf{2} & \mathbf{3} \\ \text { Tata jari } & : & \mathrm{b} & \mathrm{a} & \mathrm{b} & \mathrm{c} \\ \text { Kosokan } & : & / & \backslash & / & \backslash \\ \text { Not. Reb } & : & \mathbf{3} & \mathbf{1} & \mathbf{2} & \mathbf{3} \\ \text { Tata jari } & : & \mathrm{c} & \mathrm{b} & \mathrm{a} & \mathrm{c} \\ \text { Kosokan } & : & / & \backslash & / & \backslash \\ \text { Not. Reb } & : & \mathbf{y} & \mathbf{1} & \mathbf{2} & \mathbf{3} \\ \text { Tata jari } & : & - & \mathrm{b} & \mathrm{a} & \mathrm{c} \\ \text { Kosokan } & : & / & \backslash & / & \backslash \\ \text { Not. Reb } & : & \mathbf{3} & \mathbf{3} & \mathbf{2} & \mathbf{3} \\ \text { Tata jari } & : & \mathrm{c} & \mathrm{c} & \mathrm{b} & \mathrm{c}\end{array}$

Pola latihan tersebut dilakukan berulang-ulang hingga siswa betul-betul dapat menemukan nadanada yang dimaksud melalui kosokan yang benar. Latihan tersebut juga dimaksudkan untuk membiasakan kerjasama antara tangan kanan, tangan kiri, gerakan kosokan, dan mata. Tangan kanan bertugas mengatur jalannya kosokan (maju dan

\begin{tabular}{cccc}
$/$ & $\backslash$ & $/$ & $\backslash$ \\
$\mathbf{2}$ & $\mathbf{1}$ & $\mathbf{2}$ & $\mathbf{y}$ \\
\hline $\mathrm{b}$ & $\mathrm{a}$ & $\mathrm{b}$ & $-\mathrm{T}$ \\
$/$ & $\backslash$ & $/$ & $\backslash$ \\
$\mathbf{2}$ & $\mathbf{1}$ & $\mathbf{2}$ & $\mathbf{y}$ \\
\hline $\mathrm{b}$ & $\mathrm{a}$ & $\mathrm{b}$ & $-\mathrm{T}$ \\
$/$ & $\backslash$ & $/$ & $\backslash$ \\
$\mathbf{3}$ & $\mathbf{2}$ & $\mathbf{1}$ & $\mathbf{y}$ \\
$\mathrm{c}$ & $\mathrm{b}$ & $\mathrm{a}$ & $-\mathrm{T}$ \\
$/$ & $\backslash$ & $/$ & $\backslash$ \\
$\mathbf{2}$ & $\mathbf{1}$ & $\mathbf{2}$ & $\mathbf{y}$ \\
\hline $\mathrm{b}$ & $\mathrm{a}$ & $\mathrm{b}$ & $-\mathrm{T}$
\end{tabular}

mundur) pada titik nada, tangan kiri memidak nada yang diinginkan, sedang mata melihat notasi yang tertulis, ketiganya harus berjalan secara sinergi. Bagi siswa-siswi tingkat sekolah dasar, keberlangsungan latihan ini tidak mudah, karena praktik memainkan rebab ini merupakan hal yang baru, sehingga dibutuhkan kesabaran ekstra dalam 
membimbingnya. Untuk mengenalkan latihan dasar 1 ini dibutuhkan waktu minimal 10 kali tatap muka dengan durasi masing-masing 60 menit dengan

\section{Dasar 2}

\section{a. Posisi 1 (mbalung)}

$\begin{array}{rlllll}\text { Not. Bal } & : & \mathbf{2} & \mathbf{1} & \mathbf{2} & \mathbf{3} \\ \text { Kosokan } & : & / & \backslash & / & 1 \\ \text { Not. Reb } & : & 2 & 1 & 2 & 3 \\ \text { Tata jari } & : & \text { a.1 } & \text { b.1 } & \text { a.1 } & \text { c.1 }\end{array}$

$\begin{array}{llllll}\text { Not. Bal } & : & \mathbf{3} & \mathbf{3} & \text {. } & \text {. } \\ \text { Kosokan } & : & / & 1 & / & 1 \\ \text { Not. Reb } & : & 3 & 3 & 2 & 3 \\ \text { Tata jari } & : & \text { c.1 } & \text { c.1 } & \text { b.1 } & \text { c.1 }\end{array}$

$\begin{array}{llllll}\text { Not. Bal } & : & \mathbf{5} & \mathbf{6} & \mathbf{5} & \mathbf{3} \\ \text { Kosokan } & : & / & 1 & / & 1 \\ \text { Not. Reb } & : & 3 & 1 & 2 & 3 \\ \text { Tata jari } & : & \text { c.1 } & \text { a.1 } & \text { b.1 } & \text { c.1 }\end{array}$

$\begin{array}{llllll}\text { Not. Bal } & : & \mathbf{2} & \mathbf{1} & \mathbf{2} & \mathbf{3} \\ \text { Kosokan } & : & / & 1 & / & 1 \\ \text { Not. Reb } & : & 2 & 1 & 2 & 3 \\ \text { Tata jari } & : & \text { b.1 } & \text { a.1 } & \text { b.1 } & \text { c.1 }\end{array}$

\section{b. Posisi 2 (mbalung)}

$\begin{array}{llllll}\text { Not. Bal } & : & \mathbf{2} & \mathbf{1} & \mathbf{2} & \mathbf{3} \\ \text { Kosokan } & : & / & 1 & / & 1 \\ \text { Not. Reb } & : & \mathbf{2} & 1 & 2 & 3 \\ \text { Tata jari } & : & \text { b.1 } & \text { a.1 } & \text { b.1 } & \text { c.1 } \\ \text { Not. Bal } & : & \mathbf{3} & \mathbf{3} & \text {. } & \text {. } \\ \text { Kosokan } & : & / & 1 & / & 1 \\ \text { Not. Reb } & : & 3 & 5 & 6 & 6 \\ \text { Tata jari } & : & \text { c.2 } & \text { c.2 } & \text { b.2 } & \text { c.2 }\end{array}$

rincian 10 menit untuk menerangkan, 10 menit untuk tanya jawab, dan 40 menit untuk praktik.

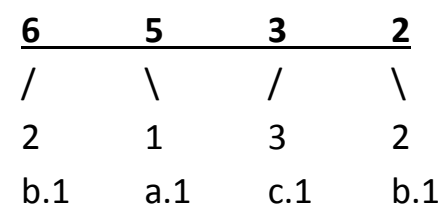

\begin{tabular}{llll}
$\mathbf{2}$ & $\mathbf{1}$ & $\mathbf{2}$ & $\mathbf{y}$ \\
\hline$/$ & $\backslash$ & $/$ & 1 \\
2 & 1 & 2 & $y$ \\
b.1 & a.1 & b.1 & -
\end{tabular}

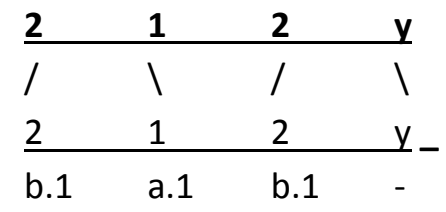

\begin{tabular}{llll}
$\mathbf{2}$ & $\mathbf{1}$ & $\mathbf{2}$ & $\mathbf{y}$ \\
\hline$/$ & 1 & $/$ & 1 \\
$\mathbf{2}$ & 1 & 2 & y \\
b.1 & a.1 & b.1 & - \\
$\mathbf{6}$ & $\mathbf{5}$ & $\mathbf{3}$ & $\mathbf{2}$ \\
\hline$/$ & 1 & $/$ & 1 \\
3 & 3 & 2 & 3 \\
c & a & b & a.2
\end{tabular}




$\begin{array}{llllll}\text { Not. Bal } & : & \mathbf{5} & \mathbf{6} & \mathbf{5} & \mathbf{3} \\ \text { Kosokan } & : & / & 1 & / & 1 \\ \text { Not. Reb } & : & 5 & 6 & 5 & 3 \\ \text { Tata jari } & : & \text { b.2 } & \text { c.2 } & \text { b.2 } & \text { c.2 }\end{array}$

\begin{tabular}{llll}
$\mathbf{2}$ & $\mathbf{1}$ & $\mathbf{2}$ & $\mathbf{y}$ \\
\hline$/$ & $\backslash$ & $/$ & 1 \\
2 & 1 & 2 & y \\
b.1 & a.1 & b.1 & -
\end{tabular}

$\begin{array}{llllll}\text { Not. Bal } & : & \mathbf{2} & \mathbf{1} & \mathbf{2} & \mathbf{3} \\ \text { Kosokan } & : & / & 1 & / & 1 \\ \text { Not. Reb } & : & \underline{2} & 1 & 2 & 3 \\ \text { Tata jari } & : & \text { b.1 } & \text { a.1 } & \text { b.1 } & \text { c.1 }\end{array}$

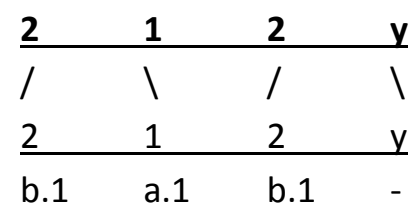

\section{c. Posisi 3 (mbalung)}

\begin{tabular}{llllll} 
Not. Bal & $:$ & \multicolumn{1}{c}{} &. & $\mathbf{6}$ &. \\
Kosokan & $:$ & $/$ & 1 & $/$ & 1 \\
Not. Reb & $:$ & 6 & 6 & 6 & 6 \\
Tata jari & $:$ & a.3 & a.3 & a.3 & a.3
\end{tabular}

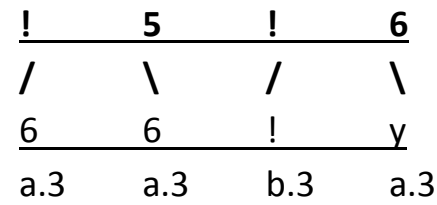

$\begin{array}{llllll}\text { Not. Bal } & : & \mathbf{3} & \mathbf{5} & \mathbf{6} & \mathbf{!} \\ \text { Kosokan } & : & / & 1 & / & 1 \\ \text { Not. Reb } & : & ! & ! & 6 & ! \\ \text { Tata jari } & : & \text { b.3 } & \text { b.3 } & \text { a.3 } & \text { b.3 } \\ \text { Not. Bal } & : & \ddots & \text {. } & \mathbf{6} & \text { ! } \\ \text { Kosokan } & : & / & 1 & / & 1 \\ \text { Not. Reb } & : & 6 & 6 & 6 & 6 \\ \text { Tata jari } & : & \text { a.3 } & \text { a.3 } & \text { a.3 } & \text { a.3 } \\ \text { Not. Bal } & : & ! & ! & \mathbf{3} & \mathbf{2} \\ \text { Kosokan } & : & / & 1 & / & 1 \\ \text { Not. Reb } & : & ! & ! & 3 & 2 \\ \text { Tata jari } & : & \text { b.3 } & \text { b.3 } & \text { c.1 } & \text { b.1 }\end{array}$

\begin{tabular}{llll}
$\mathbf{6}$ & $\mathbf{5}$ & $\mathbf{3}$ & $\mathbf{2}$ \\
\hline$/$ & 1 & $/$ & 1 \\
3 & 2 & 1 & 2 \\
\hline c.1 & b.1 & a.1 & - \\
$!$ & $\mathbf{5}$ & $!$ & $\mathbf{6}$ \\
\hline$/$ & 1 & $/$ & 1 \\
6 & 6 & $!$ & y \\
\hline a.3 & a.3 & b.3 & a.3 \\
$\mathbf{3}$ & $\mathbf{1}$ & $\mathbf{2}$ & $\mathbf{6}$ \\
\hline$/$ & $\backslash$ & $/$ & 1 \\
3 & 1 & 2 & y \\
\hline c. 1 & a.1 & b.1 & -
\end{tabular}

\section{Dasar 3}

\section{a. Posisi 1 dan 2 (nglagu 2 nada)}

$\begin{array}{llllll}\text { Not. Bal } & : & \mathbf{2} & \mathbf{1} & \mathbf{2} & \mathbf{3} \\ \text { Kosokan } & : & / & \backslash & / & 1 \\ \text { Not. Reb } & : & \text { j23 } & j 12 & \text { j23 } & 3 \\ \text { Tata jari } & : & \text { bc.1 } & \text { ab.1 } & \text { bc.1 } & \text { c.1 } \\ \text { Not. Bal } & : & \mathbf{3} & \mathbf{3} & \text {. } & \text {. } \\ \text { Kosokan } & : & / & \backslash & / & 1 \\ \text { Not. Reb } & : & 3 & \text { j56 } & 6 & 6 \\ \text { Tata jari } & : & \text { a.2 } & \text { bc.2 } & \text { c.2 } & \text { c.2 }\end{array}$

\begin{tabular}{llll}
$\mathbf{2}$ & $\mathbf{1}$ & $\mathbf{2}$ & $\mathbf{y}$ \\
$/$ & $\backslash$ & $/$ & $\backslash$ \\
j12 & $j 1 y$ & $j 21$ & $j 23$ \\
bc.1 & a1- & ba.1 & aa.2 \\
$\mathbf{6}$ & $\mathbf{5}$ & $\mathbf{3}$ & $\mathbf{2}$ \\
\hline$/$ & $\backslash$ & $/$ & $\backslash$ \\
3 & j12 & j23 & 3 \\
c.1 & ab.1 & bc.1 & a.2
\end{tabular}




\begin{tabular}{|c|c|c|c|c|c|c|c|c|c|}
\hline Not. Bal & : & $\underline{5}$ & 6 & 5 & 3 & $\underline{\mathbf{2}}$ & 1 & 2 & $y$ \\
\hline Kosokan & : & / & $\backslash$ & / & 1 & / & 1 & / & 1 \\
\hline Not. Reb & & 5 & 6 & 5 & jjjjjjjjjjjjjjjjj & jjjjjjjjjjjjj & jjjjjjjjjjjjjj & jjjjjjjjjjjjj & jjjjjjjjjj56 \\
\hline & 2 & \multicolumn{4}{|c|}{ jjjjjjjjjjjjjjjjjjjjjjjjjjjjjjjjjjjjjjjjjjjjjjjjjjjj1y } & \multicolumn{2}{|c|}{ jjjjjjjjjjjjjjjjjjjjji21 } & y & \\
\hline Tata jari & : & b.2 & c. 2 & b.2 & c.2 & b.1 & a.1 & b.1 & - \\
\hline Not. Bal & : & $\underline{\mathbf{2}}$ & 1 & 2 & 3 & $\underline{2}$ & 1 & 2 & $y$ \\
\hline Kosokan & : & I & 1 & / & 1 & / & 1 & / & 1 \\
\hline Not. Reb & : & $\mathrm{j} \underline{23}$ & ¡12 & j23 & 3 & j12 & iiiiiiily & i21 & $y$ \\
\hline Tata jari & : & b.c.1 & a.b.1 & b.c.1 & c. 1 & a.b.1 & a1- & b.a.1 & - \\
\hline
\end{tabular}

\section{b. Posisi 3 (nglagu 2 nada)}

\begin{tabular}{|c|c|c|c|c|c|c|c|c|}
\hline Not. Bal & . & & 6 & & $!$ & 5 & $!$ & 6 \\
\hline Kosokan & I & 1 & I & 1 & I & 1 & I & 1 \\
\hline Not. Reb & 6 & 6 & 6 & 6 & 6 & 6 & $!$ & $y$ \\
\hline Tata jari & a. 3 & a. 3 & a. 3 & a. 3 & a. 3 & a. 3 & b. 3 & a.3 \\
\hline Not. Bal & $\underline{3}$ & 5 & 6 & $!$ & $\underline{6}$ & 5 & 3 & 2 \\
\hline Kosokan & I & 1 & I & 1 & I & 1 & I & 1 \\
\hline Not. Reb & @ & $@$ & !@ & !@ & 6 & 3 & 12 & 56 \\
\hline Tata jari & c3 & c. 3 & b.c3 & b.c. 3 & a.3 & c.1 & a b.1 & a a. 3 \\
\hline Not. Bal & : & 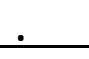 & 6 & • & $!$ & 5 & $!$ & 6 \\
\hline Kosokan & / & 1 & / & 1 & / & 1 & / & 1 \\
\hline Not. Reb & 6 & 6 & 6 & 6 & $@$ & $\#$ & $!$ & $\mathrm{y} !$ \\
\hline Tata jari & a.3 & a. 3 & a. 3 & a. 3 & c. 3 & d. 3 & b. 3 & a b. 3 \\
\hline Not. Bal & $!$ & $!$ & 3 & 2 & $\underline{3}$ & 1 & 2 & 6 \\
\hline Kosokan & / & 1 & / & 1 & / & 1 & / & 1 \\
\hline Not. Reb & 3 & 2 & 1 & j23 & j12 & j1y & $\mathrm{j} 21$ & $y_{-}$ \\
\hline Tata jari & c. 1 & b.1 & a.1 & b c.1 & a b.1 & a.1 - & b.a.1 & - \\
\hline
\end{tabular}

\section{PENUTUP}

$$
\text { Telah diuraikan pada }
$$

pembahasan sebelumnya bahwa hadirnya Karawitan Jawa diperuntukkan bagi kalangan orang dewasa, baik pada praktik klasikal maupun individual. Khususnya praktik individual rebab dalam pemahaman tradisi baru boleh dipelajari apabila pemain sudah memahami instrumen-instrumen lain. Akan tetapi praktik individual rebab dalam konteks pendidikan dapat dilakukan sedini mungkin, bahkan sejak anak usia sekolah dasar klas 4 sudah dapat dikenalkan.

Langkah tersebut sudah tentu dibutuhkan cara atau metode khusus untuk menunjang proses pembelajaran. Melalui uraian yang telah dipaparkan sebelumnya, dapat disimpulkan bahwa metode yang digunakan pada pembelajaran praktik instrumen rebab bagi anak usia sekolah dasar setidaknya ada 2 macam, yaitu 
penggunaan instrumen dan notasi dasar. Kedua macam elemen tersebut setelah diaplikasikan pada siswa-siswi SDN Kasihan, SDN Karanggondang, dan SDN Bangunharjo sebagai sampel, ternyata dapat diserap dengan cukup baik sesuai dengan tingkat usianya. Kecuali kedua elemen yang dijadikan metode khusus, dalam proses pembelajarannya dibutuhkan ketelatenan dan kesabaran sebagaimana mengajarkan mata pelajaran lain.

\section{DAFTAR PUSTAKA}

Dewantara, Ki Hadjar (1967). Kebudajaan. Yogyakarta: Madjelis Luhur Taman Siswa.

(1962). Seni Pendidikan. Yogyakarta: Taman Siswa.

Djoko Walujo, (1981). “Belajar Rebab" . Diktat tanpa penerbit.

Djumadi, (1982). "Tuntunan Belajar Rebab". Surakarta: SMKI Surakarta. (1975) "Titilaras Rebaban Jilid II". Surakarta: ASKI Surakarta.

Kriswanto, (1986). "Uyon-uyon Hadiluhung Karaton Yogyakarta Hadiningrat". Tugas Akhir Sarjana S-1. Yogyakarta: Institut Seni Indonesia Yogyakarta.

(2012). "Uyon-Uyon Hadiluhung Kraton Yogyakarta: Sebuah Media Pembentukan Karakter". Laporan Penelitian dibiayai oleh DIPA ISI Yogyakarta tahun 2012. Yogyakarta: LPT ISI Yogyakarta.

Martopangrawit. 1975. "Pengetahuan Karawitan I, II". Surakarta: Akademi Seni Karawitan Indonesia.
Raharja, (1996). "Rebaban Sulukan Wayang Kulit Purwo Gaya Yogyakarta Versi Ki Suhardi". Yogyakarta: Jurusan Karawitan.

Rusli, Agus, (1976). Buku Petunjuk Pendidikan Dasar Musik Anak-anak. Jakarta: Proyek Koservatori DKI, Direktorat Kesenian, Direktorat Jenderal Kebudayaan, Departemen Pendidikan dan Kebudayaan, Jakarta

Sedyawati, Edi, (1981). Pertumbuhan Seni Pertunjukan. Jakarta: Sinar Harapan.

Soedarsono at.al., (1977/1978). "Kamus Istilah Tari dan Karawitan Jawa". Jakarta: Proyek Penelitian Bahasa dan Sastra Indonesia dan Daerah. . : 203)

Soeroso, (1984). "Lagu Dolanan SlendroPelog". Yogyakarta: Jurusan Musik ISI Yogyakarta.

Suhastjarja, R.M. AP. et.al., (1984/1985). "Analisa Bentuk Karawitan". Laporan Pelaksanaan Penelitian Sub/Bag. Proyek Akademi Seni Tari Indonesia Yogyakarta Departemen Pendidikan dan Kebudayaan.

Sumanto, Wasty, (!983). Psikologi Pendidikan. Malang: Bina Aksara.

Supanggah, Rahayu. 1990. "Karawitan Anak-Anak" Dalam Seni Pertunjukan Indonesia, Jurnal MMI (Masyarakat Musikologi Indonesia), Surakarta

Surat Edaran LP2M, (2015). "Panduan Pengelolaan Penelitian/Penciptaan/ Perancangan Karya Seni Dosen Muda". Yogyakarta: Lembaga Penelitian dan Pengabdian Pada Masyarakat ISI Yogyakarta. 